\title{
Critical thinking and use of film in Norwegian lower secondary history classrooms
}

\author{
David-Alexandre Wagner* - University of Stavanger, Norway
}

\begin{abstract}
This article examines how Norwegian social studies teachers from lower secondary schools enhance critical thinking when using film in the history classroom. We utilized empirical data from semi-structured interviews with 20 teachers from the same regional area in Norway. The article addresses several questions: What are the teachers' impressions of their students' and their own abilities to be critical towards films? Do they use film to meet competence aims in the curriculum for eighth to tenth grade? Do they use film to enhance students' critical thinking abilities? If so, how? The teachers' answers seem paradoxical. Although they mostly consider critical thinking abilities towards film to be crucial for eighth- to tenthgrade students, who usually lack them, most of the teachers did not clearly link their frequent use of film in the classroom to the development of critical historical thinking skills and dispositions, neither in their alleged goals nor in their actual practices. Although they partly recognized the empathetic value of history films and their worth for debate, the teachers generally overlooked a whole part of their potential. These results are consistent with those of other international studies. They probably bear witness to the predominance of a scientific conception of the use of history in school, rooted in epistemological beliefs that would need to be studied more closely in order to sustain perennial practice changes in the future.
\end{abstract}

Keywords: Norway; critical thinking; film, historical understanding; history classroom; history education; visual literacy

\section{Introduction}

There seems to be a general consensus among policymakers, employers, educators and parents about the importance of critical thinking, as a set of competences and of attitudinal dispositions, for students' future professional and personal lives as empowered citizens of democratic societies in the twenty-first century (Koenig, 2011: 1; Pithers and Soden, 2000: 237). In Norway, this concern has been reflected in the Standard Core of Competences and Knowledge since the Knowledge Promotion Reform of 2006 (hereafter called K06) (Johanson, 2015: 3-4; Utdanningsdirektoratet, 2009), and in the 2015 report The School of the Future (Ludvigsen Committee, 2015: 8-10) that announces the next education reform. For social studies and history education in particular, the $\mathrm{KO} 6$ aimed at a paradigmatic shift. From the construction and reinforcement of a national identity around a common national narrative, during the nineteenth and twentieth centuries, history education has moved towards acknowledging diversity and enhancing critical and analytical competences, connected to the concepts of historical consciousness, uses of the past and historical thinking (Bøe, 2006; Koritzinsky, 2014; Kvande and Naastad, 2013; Lund, 2011). Nevertheless, it is generally admitted that the Norwegian education system grants teachers a lot of 
freedom of action and interpretation regarding the Standard Core; many teachers are still quite attached to textbooks and to traditionally teaching facts (Koritzinsky, 2014), and the K06 and the textbooks are unclear about the concepts related to historical thinking (Johanson, 2015). In this regard, the new Education Reform, expected to be implemented in autumn 2020, aims at focusing on in-depth learning, critical thinking, ethical consciousness and democratic citizenship to equip students with the context behind fast-evolving economies and societies (Sanner, 2018). This is in line with the relevance of digital and media literacies in twenty-first century skills (Ananiadou and Claro, 2009) for citizens in democratic societies overwhelmed by a growing flow of digital and visual media in the last two decades and now under attack from a posttruth culture (Journell, 2017). For social studies, and history particularly, this entails prioritizing core elements including historical thinking/historical literacy and historical consciousness (Ekroll and Helland, 2017), in addition to media and film literacy as a basic competence (Ludvigsen Committee, 2015: 8-10).

However, although history films seem to be one of the resources most used in the history class in Norway (Wagner, 2018), as in many other developed countries (Boutonnet, 2013: 108-9; Donnelly, 2010: 1; Héry-Vielpeau, 2012: 1; Marcus et al., 2010: 3; Russell, 2007: 6; Wehen, 2012: 51), there has been so far no study of how Norwegian lower secondary school teachers integrate critical thinking activities when using films. The purpose of this article is to fill a part of this gap by presenting some results from a qualitative survey performed in 2016 among 20 lower secondary school teachers from the same regional area in Norway.

\section{Theoretical framework: Teaching critical thinking with history film}

The major role that history films play in disseminating, representing and influencing people's beliefs about the past has been widely acknowledged (Ferro, 1993; O'Connor, 1988; Seixas, 1994; Wineburg et al., 2001). As such, history films contribute to the public discourse about the past (Rosenstone, 2006) and have become a common resource in history classrooms (Donnelly, 2010: 1; Marcus et al., 2010: 3; Wagner, 2018: 23). In addition, despite a lore of stereotypes and research studies about teachers' non-purposeful uses of film in the classroom (Hobbs, 1999, 2006), the potential of film for teaching history in school has also been largely recognized. Beyond being a lively illustration of a putative past, film can be used to develop higher-order thinking skills of critical and historical thinking (Marcus et al., 2010; Russell, 2007; Woelders, 2007). To promote critical historical thinking in relation to audiovisual representations, or what has been called a historical film literacy, has become a necessity (Metzger, 2007, 2010).

Although the concept of critical thinking has traditionally involved a battle between many competing definitions, it has been defined as a combination of skills and attitudinal dispositions (Huber and Kuncel, 2016: 434-5; Lai, 2011: 9-11). Critical thinking can be understood as the ability to perceive the relationships between text, in a broad sense, and context (Freire and Macedo, 1987: 29), and to deduce and evaluate conclusions from information or data, as well as to gauge their validity and authority as evidence (Pascarella and Terenzini, 1991: 118). Critical pedagogical approaches may also be added to those skills that spur students to materialize their critical thinking through actions (for example, by performing social actions, conducting research and presenting their understandings publicly) (Fajardo, 2015). Critical thinking can also be defined as a reflexive attitude that is not limited to texts (of all kinds), but that is required for a large range of tasks (such as investing money, driving a car, shopping 
or making political choices) (McPeck, 1984: 30). In that sense, it is not only a general ability but almost always a domain-specific competence that needs some field-specific expertise (Kuncel, n.d.; McPeck, 1981).

Still, how do we define critical historical thinking when we want to address the beliefs and practices regarding history films of our Norwegian teachers? We have chosen different concepts related to historical thinking: sourcing, contextualization, close reading and corroboration (Wineburg, 2010); the Big Six (Lévesque, 2008; Seixas and Morton, 2013): historical significance, historical evidence, continuity and change, causes and consequences, historical perspectives, ethical dimensions; and also the concept of historical consciousness introduced by Jörn Rüsen in the 1970s (Seixas, 2004), and the notion of history as a construct about the past (White, 1988). We have also added pedagogical practices enhancing a shared authority between teacher and students, and engaging and supporting students' dialogue and initiatives (Robinson, 2011).

Although the research about teaching history through film was abundant in the first half of the twentieth century, these surveys were most often quantitative and offered poor results. Since the 1960s and the cognitive revolution initiated in the 1980s, the research has been much scarcer and has changed focus towards qualitative studies investigating the potential of film to enhance historical thinking (Marcus and Stoddard, 2007: 588; Paxton and Marcus, 2018; Stoddard, 2012: 273). The goal of this study is to identify how a sample of Norwegian history teachers asserted that they utilize films in their social studies classes in order to promote critical historical thinking. We have analysed them through the lens of a supposed effective utilization, implying that history film can be used to promote in-depth learning and high-order thinking skills that go beyond the acquisition of factual knowledge.

\section{Former studies}

A number of international surveys, of varying natures, have been performed about teachers' use of film in the history or the social studies classroom. In France, Poirier (1995) and her team gathered answers from 314 history teachers from lower secondary schools $(\mathrm{N}=226)$ and high schools $(\mathrm{N}=88)$ across France. Among the 57 questions asked by Poirier, only one question directly concerned the use of films in relation to critical literacy; it asked teachers whether they believed that teachers generally used films to serve as historical sources or rather to instil content knowledge. Only 9 per cent answered that they used films as sources, while 29 per cent answered that they did both (Poirier, 1995: 25). However, three other indirect questions brought to light that a critical use of film was reserved for high school and was not a reality at lower secondary level (ibid.: 74).

In the USA, William B. Russell's (2012) online survey of 249 social studies teachers from secondary schools is difficult to interpret and did not shed light on their practices related to critical thinking. On the other hand, Marcus and Stoddard's (2007) seminal study, of 85 high school teachers from Wisconsin and Connecticut, underlined that only a handful of their respondents mentioned using film as a representation of history or an alternative historical source. They mainly used films as an illustration of the past, thus exploiting the empathetic power of the movies, but little is known about their use of film to enhance critical thinking (Marcus and Stoddard, 2007: 308-12).

In Australia, Debra Donnelly $(2010,2014)$ performed a substantial study on 203 teachers, followed up by in-depth interviews $(\mathrm{N}=30)$ and classroom observations $(\mathrm{N}=6)$. A very small proportion (8 per cent) of the respondents cited film as a useful 
medium to teach historiography and the nature of historical knowledge; few teachers applied source analysis techniques to films, commented on the ways films manipulate the audience, or connected film with issues of historical thinking or the constructive nature of historical representations. There was an overall neglect of teaching explicitly about historical representation and critical literacy skills. However, some teachers addressed issues related to historical consciousness, and a large majority (72 per cent) encouraged empathy as perspective-taking, but they generally felt uncomfortable with the empathetic power of the movies and its link to caring and taking action or demonstrating citizenship (Donnelly, 2014: 7-11).

In the UK, Blake and Cain (2011) carried out a survey gathering postal questionnaires from 30 secondary school teachers (teaching 11-18 year olds) from North-East England. While a number of teachers routinely developed historical consciousness using films, they generally did not approach films as historical sources or as resources to enhance critical or historical thinking (Blake and Cain, 2011: 94).

In Germany, Britta Almut Wehen (2012) carried out an online survey with teachers from fifth to twelfth grade $(\mathrm{N}=274)$ from a few Länder. History films were mainly a conveyor of subject content matter and were infrequently examined as a source or a representation of the past. In addition, more than 50 per cent of the respondents considered that films generally gave an authentic image of the past. However, the same proportion discussed in class the relationship between films and their students' historical consciousness (Wehen, 2012: 51-5).

In Québec, Sasseville and Marquis (2015) interrogated 52 secondary school history teachers over the phone before conducting in-depth interviews with 6 of them. None of their respondents $(\mathrm{N}=52)$ mentioned film as a method of teaching historical thinking, but some of them spoke of it in relation to the understanding of complex concepts. The school activities were chiefly about the explicit content of the films and its value as an illustration of subject matter (Sasseville and Marquis, 2015: 20).

In Scandinavia, the practices of a limited number of high school teachers were investigated in Sweden ( $N=8$ ) (Hultkrantz, 2016) and in Norway ( $N=19)$ (Wagner, 2018). Hultkrantz read these practices through the lens of Klas-Göran Karlsson's typology of the uses of history (Karlsson, 2004). She managed to characterize general modalities and challenges, and to identify six different strategies of film use. Some of these are closely related to critical thinking activities, but she did not address this aspect specifically, and the size of her sample limits them to individual cases. Wagner's study touched upon the same questions for Norwegian high school teachers as our survey, but on critical thinking aspects it did not reveal as much detail as the present survey. It appears that a little more than 30 per cent of these high school teachers used history films to engage high-order thinking activities in practice.

\section{Our survey}

We carried out interviews with 20 social studies teachers from four lower secondary schools from the same regional area in south-west Norway. Lower secondary school in Norway encompasses three years from eighth to tenth grade (ages 13-15) after elementary school (ages 6-12) and before upper secondary (ages 16-18). Admission to upper secondary school requires students to choose specialisms, and it is competitive: all students applying will be admitted somewhere, but not necessarily to their first choice of school. Social studies includes three main topics: history, society and geography. In our sample, a majority of teachers devoted an equal amount of time to each topic. The standard is three history lessons (two and a half hours) a week over 11 weeks 
annually. The other teachers allocated less time to geography, while treating history and society equally, or assigned a little more time to history. The history curriculum in eighth grade covers Norway's history, the revolutions in Western countries and the development of nationalism and imperialism from the end of the eighteenth century until the beginning of the twentieth century. The ninth grade deals with the period of the two world wars, while tenth grade comprises world history since 1945. Norwegian teachers usually teach at least two different subjects, English and mathematics for example, and usually follow the same classes in these disciplines from the eighth to tenth grade. Teacher education varies from one to three years, in addition to at least one year in pedagogy.

We recruited 20 teacher volunteers and conducted a semi-structured in-depth interview with each of them. We followed the formal ethical rules of confidentiality and personal data protection required by the Norwegian Social Science Data Services (NSD). The participants volunteered freely, and were informed that their interviews would be anonymized and that they could withdraw from the study at any point and without explanation. Participants were selected following a convenience sample (Highhouse and Gillespie, 2009; Thagaard, 1998: 111).

Table 1 provides information about our respondents' school, gender, age and years of experience. Our sample is a convenience sample that is geographically coherent and fairly balanced regarding gender (9 women, 11 men) and years of experience (with nearly equal numbers of men and women in each category), but heterogeneous with regard to school and age: teachers from Schools $C$ and D are over-represented, and eight out of nine female interviewees were age 36 to 55 , while the majority of male respondents were age 26 to 35 .

Table 1: School, gender and years of experience of the interviewed teachers

\begin{tabular}{|c|c|c|c|c|}
\hline School & Informant & Gender & Age & Years of experience \\
\hline \multirow[t]{2}{*}{ A } & 9 & M & $26-35$ & $1-5$ \\
\hline & 15 & $\mathrm{~F}$ & $36-45$ & $1-5$ \\
\hline \multirow[t]{3}{*}{ B } & 6 & M & $26-35$ & $6-10$ \\
\hline & 8 & $\mathrm{~F}$ & $36-45$ & $6-10$ \\
\hline & 14 & $\mathrm{~F}$ & $26-35$ & $6-10$ \\
\hline \multirow[t]{6}{*}{ C } & 4 & $\mathrm{~F}$ & $46-55$ & $1-5$ \\
\hline & 5 & $\mathrm{~F}$ & $36-45$ & $1-5$ \\
\hline & 7 & M & $26-35$ & $6-10$ \\
\hline & 10 & $\mathrm{~F}$ & $46-55$ & $16-25$ \\
\hline & 11 & M & $36-45$ & $16-25$ \\
\hline & 19 & $\mathrm{M}$ & $46-55$ & $1-5$ \\
\hline \multirow[t]{9}{*}{$D$} & 1 & M & $26-35$ & $6-10$ \\
\hline & 2 & $\mathrm{~F}$ & $46-55$ & $6-10$ \\
\hline & 3 & M & $36-45$ & $6-10$ \\
\hline & 12 & M & $26-35$ & $6-10$ \\
\hline & 13 & M & $36-45$ & $6-10$ \\
\hline & 16 & M & $26-35$ & $1-5$ \\
\hline & 17 & $\mathrm{~F}$ & $36-45$ & $6-10$ \\
\hline & 18 & M & $46-55$ & $>25$ \\
\hline & 20 & $\mathrm{~F}$ & $46-55$ & $>25$ \\
\hline
\end{tabular}




\section{Validity and reliability}

All interviews were performed in Norwegian, following 24 set questions about how and why film was used in the history classroom and allowing the interviewees to explain their practices freely. Following Sasseville and Marquis (2015: 3), we defined history films as diverse audiovisual documents, including feature films, documentaries and television series. The duration of the interviews varied, with the shortest lasting 28 minutes and the longest lasting 73 minutes; the average was 45 minutes. All answers were audio-recorded, transcribed, and subsequently coded and analysed using NVivo12, following a conventional inductive content analysis (Hsieh and Shannon, 2005: 1279; Zhang and Wildemuth, 2017: 319). We did not explicitly test hypotheses from already existing theories, but tried to ground our analysis in the data. We established a first list of coding categories based on the concepts mentioned above and our research questions. We refined our categories over the course of the analysis and the comparison of all interviews.

This survey is qualitative and, as such, not representative nor generalizable, but it is meant to give a deeper insight into 20 secondary school teachers' practices involving film. It is clear that statistical correlations with gender, seniority or other variables would be pointless. However, we hope that this sample reflects a diversity of profiles with a transferable value. We are aware that the respondents might have under-reported nonpurposeful practices (Marcus and Stoddard, 2007: 310) and that these interviews only represent their reported practices, not their actual uses of film in the history classroom. In addition, each of them might have understood the meaning of the questions slightly differently. However, we are confident that the openness and the face-to-face format of the interviews has given us a fair picture of their beliefs. While these beliefs may not accurately mirror their actual practices, they are still interesting as being Norwegian teachers' beliefs, compared to those from teachers in other countries.

\section{Findings}

We asked the teachers many questions about their use of films in the history classroom. The results of our study are to be published in another article, and show mainly a routine and well-integrated use of film and clips in the history classroom. Almost all teachers had purposeful uses, with oral and written activities around history film. They used film for its inherent audiovisual advantages, but also as an inclusive pedagogical tool, offering to almost all students a sense of mastery that, in turn, stimulated their motivation and interest. However, the focus of this article is specifically on their use of films in relation to critical historical thinking. Thus, we selected four main questions relating to this:

(1) What are the teachers' impressions of their students' abilities to deal with the films they watch, either at school or at home, in a critical manner?

(2) Are they themselves, as teachers, aware of thinking critically in relation to film?

(3) Do they use film to meet competence aims in the eighth- to tenth-grade curriculum? Which ones, for example?

(4) Do they use film to enhance the critical thinking abilities of their students? If yes, how? 


\section{Teachers' impressions of their students' critical awareness of film}

The teachers' impressions were reflected in four different answers. Half of our respondents believed that the critical abilities of their students when watching films varied greatly from student to student, while 8 out of 20 teachers deemed them to be mostly bad or poor, and 2 informants judged them to be very good and actually much better than those of former generations. However, 6 teachers added that these abilities improved as a part of a process during the course of schooling from eighth to tenth grade. Most of the group who gauged their students to be critically poor felt, however, that this ability could be learned in class, by showing them how to be critical towards film, while a couple of informants posited that it was a matter of maturity, and that students in eighth and ninth grades were too young to learn critical thinking when watching or discussing films. A vast majority of the teachers who viewed critical abilities as varying from student to student also thought that these abilities could be taught to everyone, in particular by asking them the right questions (Who is the film made by? For whom? With what intent?). One interviewee even underlined that film made this task even easier than usual with weaker students. Only three respondents felt that this goal was out of reach because some students were too weak to learn to think critically, or as a result of lack of time.

Informant 4 is a good example of these tendencies:

It is developing, absolutely. In the eighth grade they have little understanding of critical thinking. It is all about the entertainment value of the film: 'This was fun ...' Then Fog of War is a good test. We show it in the tenth grade and it's not an amusing film, but an informative one. Then you can spot those who understand it, and even the critical aspects of it. And those who just think it was dull. So I would say there is a huge variation here ... Actually, I am one of these teachers thinking that many teachers underestimate their students' development in lower secondary. I have had many students in social studies and I really think it's possible to make them more critical, to a certain extent. Definitely not all of them, but it's about giving them enough stimuli and telling them why you chose these films in particular.

The two teachers who were positive about their students' critical skills asserted that current students had better critical abilities towards film than those of former generations, because they were much more exposed to audiovisual media or were so-called 'digital natives'.

\section{Teachers' appraisal of their own critical awareness of film}

The overwhelming majority of teachers considered themselves to have critical awareness about history films. While one informant did not answer and another one admitted that she was not critical enough because film was not her 'cup of tea', the rest of them (18 out of 20) answered 'yes' to this question. However, four of them did concede that they probably could have been more critical.

Nevertheless, the answers of half of our informants revealed a rather narrow understanding of what being critical towards history films entails. They actually exposed a tendency to associate critical thinking with the right choice of film. That 
is to say, they appeared to believe that being critical consisted of being picky and paying considerable attention to the historical accuracy of the films, choosing the 'right' sources with the 'right' content. In addition, those respondents admitted that they usually did not focus on sourcing or on the different perspectives a film could display, but mostly on the historical details of the films' narratives. This conception refers to a scientific use of history, considering history education as upholding the most accurate depiction of the past possible, and limits considerably the critical approach to historical film. The answers of informants 8 and 12 are illuminating about this issue:

Yes, but I don't do much research about the director. I wonder more about fact-checking the story. I can use fantasy films too. It just has to fit in with what I'm going to focus on. (Informant 8)

I do put a lot of trust in the NRK [the Norwegian equivalent of the BBC], using some of their clips from the editors who have done a good job, so that they are good sources. Yes, and YouTube. You have to be a little cautious with what you choose to show. Anybody could have made and posted something there. Usually I have watched the films beforehand, or talked with colleagues, and I know that these things are good sources. (Informant 12)

Moreover, a couple of teachers interpreted critical thinking as their ability to pause the film during viewing in order to give explanations about aspects of content matter that students might not have understood.

\section{Teachers' use of film to meet curricular competence aims}

When asking teachers whether they were using film to meet curricular competence aims in the history classroom, we received three types of answer. Seven informants stated that they did, and gave examples of which aims they were targeting. Informant 5 stated:

Yes: Discuss causes and consequences of central internal conflicts in the twentieth- and twenty-first centuries. And discuss the idea of human dignity and discrimination and the rise of racism in a historical perspective. And they must create narratives about people from different societies in the past and now. When we schedule our teaching and define the learning outcomes, we put the films where they fit in. That eases our work, when the students are to be assessed orally, for example. (Informant 5)

Eight teachers confessed that they did not link films to competences. Five informants said that they did, but could not mention any example of the competence addressed in the aims of the curriculum. These five teachers might have suffered from a temporary memory loss at the time of the interview, or, worse, they could be only vaguely aware of the competence aims of the curriculum they are teaching. However, if we consider that these five teachers were not purposefully using history film to address competence aims, even if they did not want to admit it overtly, including them in the figures would mean that a majority of informants did not use history film to address these aims.

Noticeably, not all the competence aims of the curriculum (Utdanningsdirektoratet, 2013) are obvious and appropriate to be used in relation to films, but a closer examination of the examples mentioned by the teachers who actively sought to cover 
the competence aims is instructive. For social studies for eighth to tenth grade, the K06 competence aims are divided into four sections: three sections with specific competences for history, society and geography respectively, and a section called 'The Researcher', gathering overarching common competences for these three subjects. Out of the 18 competence aims from 'The Researcher' and 'history', at least 13 seem pertinent and plausible to develop with the help of film. However, our subjects named only 6 of them (from the most to the fewest cited):

(1) Discuss and elaborate on the causes and effects of the key international conflicts of the 1900s and 2000s (five respondents).

(2) Discuss and elaborate on the ideal of human dignity, discrimination and the development of racism from a historical perspective with a view to the present (two respondents).

(3) Create stories about people from different societies in the past and present, and show how their living conditions and values influenced their thoughts and actions (two respondents).

(4) Present the main characteristics of the history and culture of the Sami people from the mid-1800s up to the present, and discuss and elaborate on the consequences of the Norwegian policy of Norwegianization and the Sami people's fight for their rights (one respondent).

(5) Discuss and elaborate on important changes in society in recent times and reflect on how today's society opens to new changes (one respondent).

(6) Discuss and elaborate on the ideas and forces that led to the American struggle for freedom and the French Revolution, and the consequences these had for the development of democracy in Norway (one respondent).

From the list of competence aims for eighth to tenth grade, we could actually point out at least two prominent aims that were directly connected to critical historical thinking, but that were missing from the teachers' interviews:

(1) Show how incidents can be presented in different manners and discuss how special interests and ideologies can cloud one's view about what was experienced in fact.

(2) Reflect on social science questions using information from different digital and printed sources, and discuss the objectives and relevance of one's sources.

Nevertheless, even though this may suggest that teachers are not clearly aware of the connection that can be drawn between competence aims and the use of films, they could still actually be using film to enhance critical thinking through the pedagogical activities they organize in class.

\section{Teachers' use of film to foster students' critical thinking abilities in class}

When asked directly, nearly all teachers acknowledged that prompting critical thinking when using film is important or very important. Yet, six teachers disclosed overtly that they did not do it in practice, while the other 70 per cent of our informants asserted that they did. The explanations for not doing so were three-fold and sometimes overlapping.

The first reason was that this work on critical thinking was actually done not in the history class, but in the Norwegian class, as it was an aim that was reserved for that class. It is probably linked to the fact that one specific learning outcome in the curriculum for Norwegian is about having a disciplinary dialogue about the form and 
content of a film. Thus, teachers invoked a transdisciplinary approach to their teaching, which appears quite common among our interviewees, since almost half of our panel of teachers mentioned it. Because teachers in Norwegian secondary schools teach at least two different disciplines, they do not have very rigid barriers between subjects, especially if they are not very dissimilar subjects. This means that teachers having, for example, Norwegian or English and social studies with the same class of students might plan certain activities in one subject in order to cover or rehearse competence aims within another subject.

The second reason given was that students had, unfortunately, neither the maturity nor the academic ability to work at this level (of critical thinking) before the end of tenth grade at the earliest, or usually high school. These two reasons are a way to defer one's responsibility in that matter to another school subject or on another school level.

Third, a few teachers recognized that they had never thought of adopting a critical approach to film with their students, but that it was a very good idea indeed. Symptomatically, the interview functioned as an enlightening experience and opened up teachers' minds about the pedagogical potential of film to develop critical thinking. Moreover, it emerges from our analysis that these teachers had limited goals for their use of film in the history class. Their use of film was restricted to two main aims: illustrating subject matter content and enhancing motivation and interest through varied teaching resources.

As Informant 11 put it, when asked whether he used film to enhance critical thinking:

Definitely too little. A little, but when we watch this Michael Moore film, because it is a disputed documentary ... but I feel that the class has to be at a certain level. Otherwise, only a small part of the class is able to follow ... we hope the students will reach this level but throughout the three years, not all of them do. In high school, I would certainly have done much more of it ... Well, I feel you raised good questions. You made me think about things I maybe do not consider when I use film. (Informant 11)

Still, many teachers gave satisfactory answers, and appeared very conscious about enhancing critical historical thinking with film throughout the three years of lower secondary school, as illustrated, for example, by Informants 1 and 3:

You may have taught about the Cold War and tried to show them the situation from different sources and in a critical perspective. You look at American versus Soviet newspapers - you do it in class. Afterwards, when you show a film, like Fog of War, that is seen from the American side, you ask them to discuss the film critically, in line with the competence aims. We do it in the tenth grade, but I drill them to reflect since the eighth grade, to look at things from different perspectives and discuss them. I may seem a little elusive, but my point is that it is a consistent process from the eighth to the tenth grade. (Informant 1)

I try to ask questions about the film's origins: who made it? So we can see that people have different interests in showing things from a certain angle. And I try to challenge the students. Can we trust this? Do they depict the situation in a balanced way? Do they show both sides of an issue? - Being critical in that sense. (Informant 3) 
However, the fact that as many as 14 teachers asserted that they were enhancing critical thinking in practice is puzzling, when compared with their answers to the general question about their rationales for using films in the history classroom. From Table 2 we can see that 'to develop historical and critical thinking' per se was central to only 25 per cent of our interviewees.

Table 2: Rationales for using film in the history class

\begin{tabular}{lc}
\hline Why did you use film in the history classroom? & Frequency \\
\hline Illustrate/visualize subject matter content & 20 \\
- visualizing lesson content only & 8 \\
- film brings also extra knowledge & 7 \\
- bringing the past to life/evocation of the past & 5 \\
Variation (to enhance motivation and interest) & 16 \\
Enhance empathy & 8 \\
- as perspective recognition & 4 \\
- as caring (affective approach) & 5 \\
- as simple insight & 2 \\
Develop historical and critical thinking & 5 \\
Motivation for the teacher & 2 \\
Film as a hook/introduction to a topic & 3 \\
Reward/break/replacement & 7 \\
Film is a central medium & 2 \\
An experience in common for the class & 2 \\
Appropriate resource for 'weaker' students & 2 \\
\hline
\end{tabular}

This confirms that developing historical thinking or high-order thinking skills is not a prioritized goal for teachers when they use films. Nevertheless, we admit that this list of rationales could differ from the teachers' uses of films in practice. We therefore explicitly asked our respondents how they enhanced critical thinking through film, when they said that they did this. By scrutinizing and classifying their answers to this question, we established an overall picture of the activities that they associated with critical thinking in the history classroom (see Table 3).

Table 3: Critical thinking activities declared by the teachers

\begin{tabular}{|c|c|c|c|c|c|c|c|c|c|c|c|c|c|c|}
\hline Respondent & 1 & 2 & 3 & 5 & 6 & 8 & 9 & 10 & 1214 & 15 & 16 & 18 & 19 & Total \\
\hline \multicolumn{15}{|l|}{ Disciplinary skills/activities } \\
\hline $\begin{array}{l}\text { Develop empathy as } \\
\text { perspective-taking }\end{array}$ & $x$ & & $x$ & & & & $x$ & $x$ & $x$ & $x$ & $x$ & & & 7 \\
\hline $\begin{array}{l}\text { Discuss (long-lasting) causes } \\
\text { and consequences }\end{array}$ & & & & $x$ & $x$ & & & $x$ & & $x$ & & $x$ & $x$ & 6 \\
\hline $\begin{array}{l}\text { Enhance historical } \\
\text { consciousness }\end{array}$ & & & $x$ & $x$ & & & & $x$ & & & $x$ & $x$ & $x$ & 6 \\
\hline Sourcing & $x$ & & $x$ & & $x$ & & $x$ & & & & $x$ & $x$ & & 6 \\
\hline Film as representation & & & $x$ & & & $x$ & & & & $x$ & $x$ & $x$ & & 5 \\
\hline
\end{tabular}




\begin{tabular}{|c|c|c|c|c|c|c|c|c|c|c|c|c|c|c|c|}
\hline Respondent & 1 & 2 & 3 & 5 & 6 & 8 & 9 & 10 & 12 & 14 & 15 & 16 & 18 & 19 & Total \\
\hline \multicolumn{16}{|l|}{ Disciplinary skills/activities } \\
\hline $\begin{array}{l}\text { Discuss the relationship: } \\
\text { Film-Truth-Reality }\end{array}$ & & & $x$ & & & $x$ & $x$ & & & $x$ & & & $x$ & & 5 \\
\hline $\begin{array}{l}\text { Develop empathy as } \\
\text { emotional engagement }\end{array}$ & & & $x$ & & & & & $x$ & & & & & $x$ & $x$ & 4 \\
\hline $\begin{array}{l}\text { Develop moral judgements } \\
\text { and considerations }\end{array}$ & & & $x$ & & & & & & & & & $x$ & & $x$ & 3 \\
\hline \multicolumn{16}{|l|}{ General skills/activities } \\
\hline $\begin{array}{l}\text { Defend own thoughts and } \\
\text { opinions }\end{array}$ & $x$ & $x$ & $x$ & $x$ & $x$ & & $x$ & & & & & & & & 6 \\
\hline $\begin{array}{l}\text { Scepticism as a critical } \\
\text { attitude }\end{array}$ & & & & $x$ & $x$ & & & & & & & & & & 2 \\
\hline $\begin{array}{l}\text { Engage students as active } \\
\text { citizens }\end{array}$ & & & $x$ & & & & & & & & & & $x$ & & 2 \\
\hline Total & 3 & 1 & 9 & 4 & 4 & 2 & 4 & 4 & 1 & 1 & 3 & 5 & 7 & 4 & \\
\hline
\end{tabular}

Table 3 shows that, even though certain activities are more frequently cited than others, none is cited by all teachers. This may seem surprising, when it comes to obvious general critical activities such as 'present and defend one's own thoughts and opinions', or a disciplinary skill such as 'discuss (long-lasting) causes and consequences for a historical event'.

Table 3 also shows that a majority of the listed respondents practised between three and five critical thinking activities. Yet, we can also observe a major heterogeneity between informants. For example, Informants 3 and 18 reported a wide range of activities, while Informants 2, 12 and 14 only mentioned one. Obviously, some teachers demonstrated much more focus on higher-order thinking activities than others when using films, but one can also be sceptical about the depth of critical activities when it is limited to one type, and a quite general one. For example, Informant 2 only cited one example, 'defend own thoughts and opinions'.

Table 3 shows that some activities are more frequently used than others: 'empathy as perspective-taking', 'sourcing' (as evaluating the conditions of production, the relevance, the validity and the trustworthiness of a film), 'enhancing historical consciousness', and 'defending one's own thoughts and opinions' were the most frequent. Activities such as 'to develop empathy as emotional engagement', 'to discuss ethical and moral considerations and judgements' and 'to engage students as active citizens' were neglected in comparison.

In addition, we must mention that historical consciousness was never mentioned in itself, as a proper concept, by any interviewee. We deduced this category from teachers referring to helping students to 'draw parallels between past events and today's situations and contexts'. Moreover, the category 'defending one's own thoughts and opinions' was not homogeneous. It encompassed very different levels of argumentation and justification, from a simple uttering of opinions and thoughts in groups or in a plenary, to a regular detailed confrontation and defence of arguments.

As the question asked was: 'Do you enhance critical thinking when using film? How?', some informants may have failed to mention activities listed above, even though they do carry them out in class, either by omission or because they did not associate them with their conception of work on critical thinking. On the other hand, these answers appear to be consistent with their answers in the aforementioned 
questions and the rationales given for using films (see Table 2). Besides, the free format of the interviews gave the respondents total liberty to express themselves, and we are therefore confident that they reflect their beliefs about their practices.

\section{Discussion}

The findings of our study have produced a range of paradoxes and raised a number of issues.

Very few teachers consider their students' critical abilities towards film to be sufficient. They consider them too poor, or too variable from student to student. Encouragingly, three-quarters of our respondents felt that the skills required were abilities that could be taught, and some teachers emphasize that this is part of a continuous process and that one should expect improvements in the course of the years spent in secondary school. Still, this raises at least a couple of questions and problems.

First, it is interesting to record that as many as a quarter of our respondents seem to believe that critical thinking skills (in this context, towards film) are not within everybody's reach, especially because it requires a certain maturity that weaker students lack. This reflects ongoing research debates within the field of critical thinking. Although it is generally accepted that it can be taught and improved, the question of a developmental progression of critical thinking abilities and of its range is still contested, and partly remains to be explored. Many researchers disagree as to the capacity of every adult to achieve high-order thinking skills, as in Kuhn's evaluative epistemological position (Kuhn, 1999: 23; Lai, 2011: 20-6). In relation to historical film literacy in school, it would be interesting to explore whether this is more or less the case with children aged 13 to 15, who are less constrained than adults by long-standing misconceptions and prejudices, and the level such children could eventually reach. Besides, since our sample is merely one of convenience, it would be very interesting to know whether this tendency is repeated in a larger survey, because the more pessimistic findings (although in the minority) are contrary to the very reasons why many people become teachers. It would be intriguing to examine the reasons for this assumption that 13-15-year-old students are not capable of thinking critically about historical films.

In addition, if we compare our results with the impressions of Norwegian high school history teachers in a similar survey (Wagner, 2015, 2018), it appears that the optimism of our lower secondary school teachers about improvements in the course of secondary school is over-optimistic. As a matter of fact, a higher proportion (10 out of 19) of the high school teachers interviewed considered their students' critical thinking abilities about film to be poor or insufficient. This does not necessarily mean that the students' critical skills were actually bad, but the teachers' impressions were still negatively oriented in high school.

Moreover, almost all teachers in our sample consider their own critical abilities towards film as sufficient and, in line with the general opinion from politicians, business leaders, parents and other educators, acknowledge these critical skills as a crucial necessity in the highly mediatized twenty-first century. Yet, they do not seem to prioritize these skills, either in their alleged goals for using film, or in the activities they organize around films. In fact, these features are fairly congruent with the results from the international studies mentioned above. Notwithstanding the fact that only five teachers ( 25 per cent) said that, 'to develop critical and historical thinking' was one of their primary rationales, there was little evidence that they made any connection between their use of film and the competence aims of the curriculum 
for eighth to tenth grades. This seems to confirm that, although routinely integrated in the history classroom, film is not fully treated as a historical source with its own specificities, potential and limits. As we showed, half of our sample confined their own critical awareness towards films to a knowledge-based use of history films, consisting of choosing the 'right' films with the most 'accurate' content.

Furthermore, in consonance with Blake and Cain's findings (2011: 93), teachers seem to prioritize rationales based on effective learning principles applicable to any subject, rather than those specific to learning history. Some teachers are aware of the value of history films to foster empathy as perspective-taking or some aspects of historical consciousness, but their understanding of these concepts seemed to vary and was often very vague, giving little in-depth detail about their teaching. This is another interesting issue to be explored. Of our respondents, 70 per cent claimed to enhance critical thinking skills through their practice, but their practices were very varied and with widely different components. Only a few teachers applied a large number of critical thinking strategies to film in history, while the majority of respondents rarely used those skills.

Likewise, the teachers seemed to think that only the most able students were capable of engaging with abstract ideas. The more complex the activities, and the more they required multilayered reading and understanding, the less frequently teachers employed them, which is understandable. Teachers seemed uneasy with activities such as, 'to draw moral and ethical considerations from a film', 'to engage oneself emotionally with it', or 'to engage with issues as an active citizen'. As emphasized by Donnelly (2014: 8-9), this appears to conflict with teachers' conception of history and of the necessity to maintain a 'neutral' distance in teaching it. This confirms the fact that the nature of history as constructed knowledge and narrative is scarcely discussed or studied in class. Another consequence is that it can be assumed that a number of issues about individuals' responsibilities as citizens or historical agents are seldom explored, because they raise dilemmas that teachers feel unequipped to deal with.

Overall, the lack of use of film to enhance critical and historical thinking in the history classroom could be grounded in teachers' own epistemological beliefs about the nature of history. However, the correlation between teachers' beliefs and their actual practices is still a very disputed topic and research in this area is contradictory (Fang, 1996; Khader, 2012: 73-6). A study of the gap between teachers' beliefs and practices is much needed in the Norwegian context. It would be interesting to examine whether teachers' practices tend towards an objectivist, a subjectivist or a criterialist epistemological stance towards history, or if they alternate between two of them (Maggioni et al., 2009; VanSledright and Maggioni, 2016: 140).

\section{Conclusion}

Our survey about the critical use of film, using a sample of 20 social studies teachers from four lower secondary schools in Norway, delineates some apparent paradoxes. Although most of our respondents considered themselves to be critically aware in responding to history films, and while they judged their students to lack similar critical skills, a large majority of teachers did not attempt to bridge this gap, in their goals or in their practices using films. In addition, they usually did not make clear links between the competence aims in the curriculum and their goals and practices when using history films. One can wonder why this gap exists. However, it is clear that half of these teachers thought that to be critical about film simply meant placing an emphasis on factual historical accuracy and the details conveyed by history films. Beyond this 
attachment to a scientific use of history, the potential of the films to foster historical and critical thinking seemed to be forgotten or overlooked by a large majority. This view is corroborated by the teachers' stated goals and practices when using history film in the social studies classroom. This ignorance of the potential of history films is probably rooted in teachers' own epistemological beliefs about the nature of history. As such, these epistemological beliefs would be interesting to explore in Norway. They are presumably due to the teachers' own education and experience, an education focusing on a conception of history as a scientific recovery of a given past. Such epistemological beliefs would operate in opposition to the understanding of history as a situated social, political and ideological construction. Consequently, future policies of teacher training should endeavour to nuance or dismantle a hard-line scientific conception of history when taught in schools. The new school reform, to be implemented in 2020, operates in this direction by focusing on in-depth learning and students' disciplinary and procedural competences. Nevertheless, academic professional development programmes are also needed to equip social studies teachers for these new tasks. However, there is no doubt that this task will not be plain sailing, as it will unsettle long-standing conceptions that support students' and teachers' own definition of their personal and professional identities. Nevertheless, the modalities of such processes would in turn open exciting new research opportunities.

\section{Acknowledgements}

I would like to thank Sindre Grastveit for organizing, conducting and transcribing the interviews with the 20 respondents, and Thomas Povey for his professional help in editing this text.

\section{Notes on the contributor}

David-Alexandre Wagner is Associate Professor of History and Social Studies in the Department of Cultural Studies and Languages at the University of Stravanger, Norway. He is a founder member of the Future-Pasts Group (FPG), which researches history education, memory studies and cultural history. His research focuses on history education, particularly on the use of visual media, films, comics and video games. He is currently participating in a European Union-funded school development project, Critical Literacy Awareness in Education (CLAE), working with schoolteachers in Norway and France.

\section{References}

Ananiadou, K. and Claro, M. (2009) 21st Century Skills and Competences for New Millennium Learners in OECD Countries (OECD Education Working Paper 41). Paris: OECD Publishing.

Blake, A. and Cain, K. (2011) 'History at risk? A survey into the use of mainstream popular film in the British secondary school history classroom'. International Journal of Historical Learning, Teaching and Research, 10 (1), 88-98.

Bøe, J.B. (2006) A lese fortiden: Historiebruk og historiedidaktikk. Kristiansand: Høyskoleforlaget.

Boutonnet, V. (2013) 'Les ressources didactiques: Typologie d'usages en lien avec la méthode historique et l'intervention éducative d'enseignants d'histoire au secondaire'. Unpublished PhD thesis, Université de Montréal. Online. https://tinyurl.com/y49raz6f (accessed 6 July 2019).

Donnelly, D. (2010) 'History and film project preliminary report'. Teaching History, 44 (2), 61-5.

Donnelly, D. (2014) 'Using feature films in teaching historical understanding: Research and practice'. Agora, 49 (1), 4-12.

Ekroll, O. and Helland, T. (2017) 'Hva er det egentlig samfunnsfaget ikke kan klare seg uten?'. Udirbloggen, 29 September. Online. https://tinyurl.com/y53d8c97 (accessed 6 July 2019). 
Fajardo, M.F. (2015) 'A review of critical literacy beliefs and practices of English language learners and teachers'. University of Sydney Papers in TESOL, 10, 29-56.

Fang, Z. (1996) 'A review of research on teacher beliefs and practices'. Educational Research, $38(1), 47-65$.

Ferro, M. (1993) Cinéma et histoire. Paris: Gallimard.

Freire, P. and Macedo, D. (1987) Literacy: Reading the word and the world. South Hadley, MA: Bergin and Garvey.

Héry-Vielpeau, E. (2012) L'enseignement de I'histoire et le film: L'histoire d'un apprivoisement (1920-2000). Online. https://tinyurl.com/yya6b4yo (accessed 6 July 2019).

Highhouse, S. and Gillespie, J.Z. (2009) 'Do samples really matter that much?'. In Lance, C.E. and Vandenberg, R.J. (eds) Statistical and Methodological Myths and Urban Legends: Doctrine, verity and fable in the organizational and social sciences. New York: Routledge, 247-65.

Hobbs, R. (1999) The Uses (and Misuses) of Mass Media Resources in Secondary Schools. Online. http://files.eric.ed.gov/fulltext/ED439452.pdf (accessed 6 July 2019).

Hobbs, R. (2006) 'Non-optimal uses of video in the classroom'. Learning, Media and Technology, 31 (1), 35-50.

Hsieh, H.-F. and Shannon, S.E. (2005) 'Three approaches to qualitative content analysis'. Qualitative Health Research, 15 (9), 1277-88.

Huber, C.R. and Kuncel, N.R. (2016) 'Does college teach critical thinking? A meta-analysis'. Review of Educational Research, 86 (2), 431-68.

Hultkrantz, C. (2016) 'Med vita duken som hjälpreda i historieundervisningen'. In Larsson, A. (ed.) Medier i historieundervisningen: Historiedidaktisk forskning i praktiken. Umeå: Umeå universitet, 157-78.

Johanson, L.B. (2015) 'The Norwegian curriculum in history and historical thinking: A case study of three lower secondary schools'. Acta Didactica Norge, 9 (1), Article 5, 1-24.

Journell, W. (2017) 'Fake news, alternative facts, and Trump: Teaching social studies in a post-truth era'. Social Studies Journal, 37 (1), 8-21.

Karlsson, K.-G. (2004) 'Historiedidaktik: Begrep, teori och analys'. In Karlsson, K.-G. and Zander, U. (eds), Historien är nu: En introduktion till historiedidaktiken. Studentlitteratur AB, 13-66.

Khader, F.R. (2012) 'Teachers' pedagogical beliefs and actual classroom practices in social studies instruction'. American International Journal of Contemporary Research, 2 (1), 73-92.

Koenig, J.A. (2011) Assessing 21st Century Skills: Summary of a workshop. Washington, DC: National Academies Press.

Koritzinsky, T. (2014) Samfunnskunnskap: Fagdidaktisk innføring. Oslo: Universitetsforlaget.

Kuhn, D. (1999) 'A developmental model of critical thinking'. Educational Researcher, 28 (2), 16-46.

Kuncel, N.R. (n.d.) Measurement and Meaning of Critical Thinking. Online. https://tinyurl.com/ y5o5wfgo (accessed 7 July 2019).

Kvande, L. and Naastad, N.E. (2013) Hva skal vi med historie? Historiedidaktikk i teori og praksis. Oslo: Universitetsforlaget.

Lai, E.R. (2011) Critical Thinking: A literature review: Research report. Online. https://tinyurl.com/ o3r4k74 (accessed 7 July 2019).

Lévesque, S. (2008) Thinking Historically: Educating students for the twenty-first century. Toronto: University of Toronto Press.

Ludvigsen Committee (2015) The School of the Future: Renewal of subjects and competences (Official Norwegian Report NOU 2015:8). Oslo: Ministry of Education and Research. Online. https://tinyurl.com/yy68rv6a (accessed 7 July 2019).

Lund, E. (2011) Historiedidaktikk: En håndbok for studenter og lærere. 4th ed. Oslo: Universitetsforlaget.

Maggioni, L., VanSledright, B. and Reddy, K. (2009) 'Epistemic talk in history'. Paper presented at the 13th Biennial Conference of the European Association for Research on Learning and Instruction (EARLI), Amsterdam, 25-29 August 2009.

Marcus, A.S., Metzger, S.A., Paxton, R.J. and Stoddard, J.D. (2010) Teaching History with Film: Strategies for secondary social studies. New York: Routledge.

Marcus, A.S. and Stoddard, J.D. (2007) 'Tinsel Town as teacher: Hollywood film in the high school classroom'. The History Teacher, 40 (3), 303-30.

McPeck, J.E. (1981) Critical Thinking and Education. Oxford: Martin Robertson.

McPeck, J.E. (1984) 'Stalking beasts, but swatting flies: The teaching of critical thinking'. Canadian Journal of Education, 9 (1), 28-44.

Metzger, S.A. (2007) 'Pedagogy and the historical feature film: Toward historical literacy'. Film and History: An Interdisciplinary Journal of Film and Television Studies, 37 (2), 67-75. 
Metzger, S.A. (2010) 'Maximizing the educational power of history movies in the classroom'. The Social Studies, 101 (3), 127-36.

O'Connor, J.E. (1988) 'History in images/images in history: Reflections on the importance of film and television study for an understanding of the past'. American Historical Review, 93 (5), 1200-9.

Pascarella, E.T. and Terenzini, P.T. (1991) How College Affects Students: Findings and insights from twenty years of research. San Francisco: Jossey-Bass.

Paxton, R.J. and Marcus, A.S. (2018) 'Film media in history teaching and learning'. In Metzger, S.A. and McArthur Harris, L. (eds) The Wiley International Handbook of History Teaching and Learning. New York: Wiley-Blackwell, 579-601.

Pithers, R.T. and Soden, R. (2000) 'Critical thinking in education: A review'. Educational Research, $42(3), 237-49$.

Poirier, B. (1995) Document filmique et apprentissage en histoire: Enquête sur les représentations et les pratiques des professeurs des lycées et des collèges. Paris: Institut national de recherche pédagogique.

Robinson, A. (2011) "'Thinking better, whatever one thinks": Dialogue, monologue and critical literacy in education'. Critical Literacy: Theories and Practices, 5 (2), 21-35.

Rosenstone, R.A. (2006) History on Film/Film on History. Harlow: Pearson Education.

Russell, W.B. (2007) Using Film in the Social Studies. Lanham, MD: University Press of America.

Russell, W.B. (2012) 'Teaching with film: A research study of secondary social studies teachers' use of film'. Journal of Social Studies Education Research, 3 (1), 1-14.

Sanner, J.T. (2018) 'Tale: Fornyer innholdet i skolen'. Online. https://tinyurl.com/yy9nszhp (accessed 7 July 2019).

Sasseville, B. and Marquis, M.-H. (2015) 'L'image en mouvement en classe d'univers social: Étude sur les pratiques déclarées des enseignantes et enseignants du secondaire'. Canadian Journal of Education, 38 (4), 1-23.

Seixas, P. (1994) 'Confronting the moral frames of popular film: Young people respond to historical revisionism'. American Journal of Education, 102 (3), 261-85.

Seixas, P. (ed.) (2004) Theorizing Historical Consciousness. Toronto: University of Toronto Press.

Seixas, P. and Morton, T. (2013) The Big Six Historical Thinking Concepts. Toronto: Nelson Education.

Stoddard, J.D. (2012) 'Film as a "thoughtful"medium for teaching history'. Learning, Media and Technology, 37 (3), 271-88.

Thagaard, T. (1998) Systematikk og innlevelse: En innføring i kvalitativ metode. Bergen: Fagbokforlaget.

Utdanningsdirektoratet (2009) 'History - common core subject in programmes for general studies (HIS1-02)'. Online. www.udir.no/kI06/HIS1-02?lplang=eng (accessed 7 July 2019).

Utdanningsdirektoratet (2013) 'Social studies subject curriculum (SAF1-03)'. Online. https://tinyurl. com/y2nrg2pq (accessed 7 July 2019).

VanSledright, B. and Maggioni, L. (2016) 'Epistemic cognition in history'. In Greene, J.A., Sandoval, W.A. and Bråten, I. (eds) Handbook of Epistemic Cognition. New York: Routledge, 128-46.

Wagner, D.-A. (2015) 'Lærernes kritiske tilnærming til filmbruk i historieundervisning: En undersøkelse blant Vgs-lærere i Stavanger-området'. Paper presented at the Skriv! Les! 2015 Nordisk forskerkonferanse om lesing, skriving og literacy, Stavanger, Norway, 18 May.

Wagner, D.-A. (2018) 'Teachers' use of film in the history classroom: A survey of 19 high school teachers in Norway'. Nordidactica: Journal of Humanities and Social Science Education, 1, $22-44$.

Wehen, B.A. (2012) "Heute gucken wir einen Film": Eine Studie zum Einsatz von historischen Spielfilmen im Geschichtsunterricht (Oldenburger Schriften zur Geschichtswissenschaft 12). Oldenburg: BIS-Verlag der Carl von Ossietzky Universität Oldenburg. Online. http://oops.unioldenburg.de/1385/1/wehheu12.pdf (accessed 7 July 2019).

White, H. (1988) 'Historiography and historiophoty'. American Historical Review, 93 (5), 1193-9.

Wineburg, S. (2010) 'Thinking like a historian'. Teaching with Primary Sources Quarterly, 3 (1), $2-4$.

Wineburg, S., Mosborg, S. and Porat, D. (2001) 'What can Forrest Gump tell us about students' historical understanding?'. Social Education, 65 (1), 55-8.

Woelders, A. (2007) 'Using film to conduct historical inquiry with middle school students'. The History Teacher, 40 (3), 363-95.

Zhang, Y. and Wildemuth, B.M. (2017) 'Qualitative analysis of content'. In Wildemuth, B.M. (ed.) Applications of Social Research Methods to Questions in Information and Library Science. 2nd ed. Santa Barbara, CA: Libraries Unlimited, 318-29. 